\title{
The effects of teaching and assessment methods on academic performance: a study of an Operations Management course
}

\author{
Macarena Sacristán-Díaz, Pedro Garrido-Vega, Rafaela Alfalla-Luque \& \\ María-del-Mar González-Zamora
}

To cite this article: Macarena Sacristán-Díaz, Pedro Garrido-Vega, Rafaela Alfalla-Luque \& María-del-Mar González-Zamora (2016) The effects of teaching and assessment methods on academic performance: a study of an Operations Management course, Innovations in Education and Teaching International, 53:5, 497-507, DOI: 10.1080/14703297.2015.1008546

To link to this article: http://dx.doi.org/10.1080/14703297.2015.1008546

曲 Published online: 09 Feb 2015.

Submit your article to this journal $\pi$

Џلll Article views: 196

Q View related articles $๘$

View Crossmark data $\nearrow$

Citing articles: 1 View citing articles 


\title{
The effects of teaching and assessment methods on academic performance: a study of an Operations Management course
}

\author{
Macarena Sacristán-Díaz*, Pedro Garrido-Vega, Rafaela Alfalla-Luque and \\ María-del-Mar González-Zamora
}

Department of Financial Economics and Operations Management, University of Seville, Sevilla, Spain

\begin{abstract}
Whether the use of more active teaching-learning methods has a positive impact on academic performance remains unanswered. This article seeks to contribute to the issue by conducting a study of an Operations Management course with almost 1000 students per year over three consecutive academic years. The study compares three scenarios with differing degrees of student involvement and Information Technology usage. The findings show no differences in terms of exam grades, but there is an increase in the percentage of passes in the most active scenario analysed, in which continuous assessment tests are used. Notwithstanding, student involvement in the optional assessable activities was found to be a significant factor for predicting the likelihood of passing the subject, especially when continuous assessment tests are used, since their grades show a higher correlation with exam grades.
\end{abstract}

Keywords: teaching methods; assessment; academic performance; passes; grades; logistic regression

\section{Introduction and theoretical background}

Teaching and assessment methods (hereinafter T\&AM) are usually considered to affect students' academic performance (Tejedor, 2003). However, the results of research that measures their impact on performance are inconclusive. Friday, Friday-Stroud, Green, and Hill (2006) and McLaren (2004) find that the implementation of new T\&AM has not always resulted in improved performance. By contrast, other research studies determine that improvements in T\&AM have a positive impact on student performance (Marklin Reynolds \& Hancock, 2010).

In general, improving T\&AM consists of making the students take a more active role in the teaching-learning process by carrying out different activities throughout the course. Another way of creating more active learning environments, sometimes used to complement the above method, is the use of Information Technology (IT). IT is increasingly viewed as a key resource for enabling innovative and enhanced learning experiences in management education (Holbert \& Karady, 2009; Medina-López, Alfalla-Luque, \& Arenas-Márquez, 2011; Pascual-Ezama, Camacho-Miñano, Urquía-Grande, \& Müller, 2011). Internet-based technologies are rapidly gaining acceptance as a supplement to traditional classroom instruction for management education, enriching the teaching and learning experiences for students and lecturers

*Corresponding author. Email: macarena-sd@us.es 
(Liaw, Huang, \& Chen, 2007; Medina-López, Alfalla-Luque, \& Marín-García, 2011; Wang, Wang, \& Shee, 2007). Although the promises of IT-based instruction in the literature are extensive and there is some evidence that it may enhance the classroom environment and support student learning (Arquero \& Romero-Frías, 2013; Daymont \& Blau, 2008), further empirical research would seem to be necessary (Ginns \& Ellis, 2009).

The present paper focuses on the context of the Spanish University to provide new empirical evidence by evaluating the influence of more active T\&AM on academic performance.

Academic performance is a complex concept that can be measured by various indicators, with the exam grade being the most used in previous research. There is evidence that more active T\&AM have a positive influence on the exam grade (Fish, 2008; López-Pérez, Pérez-López, \& Rodríguez-Ariza, 2011; Polito, Kros, \& Watson, 2004). However, findings to the contrary also exist, showing that more active methods do not improve results in comparison with traditional classes or seminars (Alfalla-Luque, Medina-López, \& Arenas-Márquez, 2011; Collaud, Gurtner, \& Coen, 2000; McLaren, 2004; Merril \& Galbraith, 2009; Naslund, 2005).

To a lesser extent, the pass rate of students who sit the exam (success rate) has also been used as an indicator of performance. Some research shows that more active T\&AM have a positive effect on the success rate (Arquero-Montaño, Jiménez-Cardoso, \& Joyce, 2004; Dziuban, Hartman, \& Moskal, 2004; López-Pérez et al., 2011).

As far as is known, there is no research that analyses the pass rate of enrolled students (performance rate). However, in our particular context, Spanish universities, it is also important to consider this performance indicator. The reason for this is that student absenteeism and high dropout rates are widespread problems in Spanish universities (López-Bonilla \& López-Bonilla, 2015; Sacristán-Díaz, Garrido-Vega, González-Zamora, \& Alfalla-Luque, 2012). Some studies quantify levels of absenteeism at between 10 and 35\% (Crespo-Tejero, Palomo-Vadillo, \& Méndez-Suárez, 2012). Other studies find percentages of no-shows at examinations of $31.2 \%$ (Gracia-Expósito \& De la Iglesia-Villasol, 2007) or even 49\% (Parra, Baena, Jiménez, \& Valencia, 2008). This means that each academic year has a significant percentage of students who fail the course (repeater students in the following academic year). The importance and concern for this problem is reflected by both the success and performance rates being included among other performance indicators in the Spanish University Degree Quality Assurance System. Therefore, besides the usual exam grade, this paper also focuses on these two other academic performance measures when analysing the impact of different types of T\&AM.

In view of the above, the present paper specifically poses the following research question: Do more active T\&AM help to improve academic performance?

With the aim of contributing to the prior literature, the present study also seeks to evaluate the impact of student involvement in optional assessable activities as an explanatory variable or predictor of academic performance. In this regard, Rúa-Vieytes and Gónzález-Martínez (2004) conclude that the grades achieved in tests taken during the course help to predict students' final academic performance. Meanwhile, Barkley (2006) analyses the impact of different evaluation methods (homework, quizzes and exams) on final exam grades, finding that these are influenced by the grades of mid-term exams, but not by those of assignments and questionnaires. Finally, Durán-Santomil, Maside-Sanfíz, Catorna-Agra, and 
Rodeiro-Pazos (2013) find that the final exam grade is influenced by the marks of partial tests during the course, while the ratings of active participation in the classroom and group work have no influence. To the best of our knowledge, there are no previous studies that focus on the impact of student involvement in some optional assessable activities on both the performance rate and the success rate.

Taking into account the above, a second research question is thus added: To what extent can student involvement in more active T\&AM predict academic performance?

\section{Research methodology}

\section{Subject and scenarios}

A study was conducted at the University of Seville (Spain) using data on an Operations Management (OM) second-year subject worth 9 ECTS credits that forms part of an undergraduate degree in Business Administration, compiled over three academic years. Almost 1000 students are enrolled on the course every year and are randomly split into nine different groups according to their surnames. Overcrowding is therefore rife in the subject. Another habitual problem is the high dropout rate, which results in low attendance at the first sitting of the final examination, usually well below $50 \%$ of enrolled students.

The theoretical-practical tests for the students assessment consisted of 20 theoretical multiple-choice test questions weighted at $40 \%$, plus another 20 practical multiple-choice questions weighted at $60 \%$ that the students could only answer after solving a series of problems. A survey of the students on the course some years earlier revealed that they had difficulties with practical exercises and multiple-choice tests. This led teaching staff to concentrate on these two angles and to include a greater IT use and more active T\&AM activities which, although voluntary, would be graded. This resulted in the teaching and assessment scenario evolving over three consecutive academic years. The scenarios are summarised in Table 1 and can be described as follows:

- Scenario 0 (S0): is the control scenario in which traditional teaching was used (lectures and textbook). The assessment system included only examinations (theoretical-practical multiple-choice tests, as described above). The subject website was used solely as a repository of information.

Table 1. Summary of the three teaching and assessment scenarios analysed.

\begin{tabular}{|c|c|c|c|c|}
\hline & Scenario (S) & S0 & S1 & S2 \\
\hline \multirow{3}{*}{$\begin{array}{l}\text { Optional assessable } \\
\text { activities }\end{array}$} & $\%$ of exam grade in final grade & 100 & 90 & 80 \\
\hline & $\begin{array}{l}\text { Theoretical-practical assignments } \\
\text { (weighting) }\end{array}$ & No & $\begin{array}{c}\text { Yes } \\
(10 \%)\end{array}$ & No \\
\hline & $\begin{array}{l}\text { Continuous assessment tests } \\
\text { (weighting) }\end{array}$ & No & No & $\begin{array}{l}\text { Yes } \\
(20 \%)\end{array}$ \\
\hline \multirow[t]{4}{*}{ IT support } & Website (information repository) & Yes & Yes & Yes \\
\hline & Self-assessment via web & No & Yes & Yes \\
\hline & Teaching platform (WebCT) & No & Yes & Yes \\
\hline & WebCT use for assessable activities & No & No & Yes \\
\hline
\end{tabular}


- Scenario 1 (S1): four theoretical-practical assignments were recommended as assessable activities. These were not compulsory but represented $10 \%$ of the final grade. The remaining $90 \%$ corresponded to the theoretical and practical multiple-choice examination (same structure as in S0). Self-assessment tests were also included on the subject website and the WebCT virtual platform (but were not taken into account for the final grade).

- Scenario 2 (S2): the assessable activities consisted of doing eight continuous assessment theoretical and practical multiple-choice tests via WebCT. They were not compulsory and were worth $20 \%$ of the final grade. The remaining $80 \%$ corresponded to the theoretical-practical multiple-choice examination (same structure as in S0 and S1). Non-graded self-assessment was retained but no assignments were done.

\section{Variables and measures}

The scenario and student involvement (yes/no) in the optional assessable activities were used as independent or explanatory variables (Table 2).

As for the dependent or outcome variables, academic performance was measured using three indicators: performance rate (passes over the number of students enrolled on the course), success rate (passes over the number of students that actually sat the exam) and exam grades obtained by students ( $0-10$, with 5 being the pass-grade).

Tejedor (2003) identifies five categories of variables that influence academic performance (identification, psychological, academic, educational and socio-family). Of these, three dichotomous control variables have been considered in our research (Tables 2 and 3) since they were available for the teachers: shift (morning or

Table 2. Descriptive data for variables analysed.

\begin{tabular}{|c|c|c|c|c|c|c|}
\hline \multirow{2}{*}{$\begin{array}{l}\text { No. students enrolled } \\
\text { Gender }\end{array}$} & \multicolumn{2}{|c|}{$\begin{array}{c}\text { S0 } \\
805\end{array}$} & \multicolumn{2}{|c|}{$\begin{array}{c}\text { S1 } \\
988\end{array}$} & \multicolumn{2}{|c|}{$\begin{array}{c}\text { S2 } \\
939\end{array}$} \\
\hline & $N$ & $\%$ & $N$ & $\%$ & $N$ & $\%$ \\
\hline Female & 410 & 50.93 & 536 & 54.25 & 514 & 54.74 \\
\hline Male & 395 & 49.07 & 452 & 45.75 & 425 & 45.26 \\
\hline \multicolumn{7}{|l|}{ Repeating subject } \\
\hline Yes & 374 & 46.46 & 466 & 47.17 & 431 & 45.90 \\
\hline No & 431 & 53.54 & 522 & 52.83 & 508 & 54.10 \\
\hline \multicolumn{7}{|l|}{ Shift } \\
\hline Morning & 417 & 51.80 & 546 & 55.26 & 534 & 56.87 \\
\hline Evening & 388 & 48.20 & 442 & 44.74 & 405 & 43.13 \\
\hline \multicolumn{7}{|l|}{ Did recommended activities } \\
\hline Yes & - & - & 268 & 27.13 & 492 & 52.40 \\
\hline No & - & - & 720 & 72.87 & 447 & 47.60 \\
\hline \multicolumn{7}{|l|}{ Drop-out rate } \\
\hline Students sitting exam & 331 & 41.12 & 421 & 42.61 & 484 & 51.54 \\
\hline Students not sitting exam & 474 & 58.88 & 567 & 57.39 & 455 & 48.46 \\
\hline \multicolumn{7}{|l|}{ Performance } \\
\hline Passed over enrolled & 251 & 31.18 & 314 & 31.78 & 365 & 38.87 \\
\hline \multirow[t]{2}{*}{ Passed over sat exam } & 251 & 75.83 & 314 & 74.58 & 365 & 75.41 \\
\hline & Mean & SD & Mean & SD & Mean & SD \\
\hline Exam grade & 5.67 & 1.62 & 5.40 & 1.44 & 5.61 & 1.90 \\
\hline
\end{tabular}


evening classes), gender and whether the student was repeating the subject (i.e. previously enrolled but failed the course).

\section{Statistical methods of analysis}

Two types of analysis have been carried out:

- Comparison of scenarios: analysis of differences of proportions or means (according to the performance indicator).

- Analysis of assessable activities as a predictor of academic performance: logistic regression and analysis of linear correlations (according to the performance indicator) in the two most active scenarios (S1 and S2).

Regarding the first type of analysis, proportions tests and post hoc proportions tests were done to assess the statistical significance of differences in percentages between scenarios (performance and success rates). For the performance indicator exam grades, an ANOVA was conducted to compare the means of the three scenarios. The Levene test was carried out to verify the equality of variances in the case of exam grades. Since the assumption of equal variances is not met, the robust statistical Welch test was performed. The Games-Howell method was used for post hoc comparisons not assuming equal variances (to determine the scenarios between which the differences can be seen).

For the second type of analysis, a logistic regression was carried out for the 'pass the course' performance indicator (categorical variable: $0=$ No, $1=$ Yes), and the grades for the assessable activities were correlated with those for the examination. Table 3 shows the variables and observations used in the logistic regression for S1 and S2. All statistical assumptions of logistic regression (Peng, Lee, \& Ingersoll, 2002) were checked for.

\section{Results and discussion}

\section{Comparison of scenarios}

\section{Performance rate}

The proportion test shows that differences between the three scenarios with regard to the performance rate can be considered statistically significant $(p=0.000)$, i.e. the change to more active methodologies influences the number of passes over total

Table 3. Control Variables and observations used in regressions.

\begin{tabular}{|c|c|c|c|c|}
\hline \multirow[b]{2}{*}{ Variables } & \multirow[b]{2}{*}{ Groups } & \multirow[b]{2}{*}{ Codification } & \multicolumn{2}{|c|}{ Frequency } \\
\hline & & & $\overline{\mathrm{S} 1}$ & $\overline{\mathrm{S} 2}$ \\
\hline \multirow[t]{2}{*}{ Shift } & Morning & 1 & 278 & 310 \\
\hline & Evening & 0 & 142 & 174 \\
\hline \multirow[t]{2}{*}{ Gender } & Female & 1 & 243 & 278 \\
\hline & Male & 0 & 177 & 206 \\
\hline \multirow[t]{2}{*}{ Student repeating subject } & Not repeating & 1 & 285 & 310 \\
\hline & Repeating & 0 & 135 & 174 \\
\hline \multirow[t]{2}{*}{ Doing assessable activities } & Yes & 1 & 233 & 394 \\
\hline & No & 0 & 187 & 90 \\
\hline
\end{tabular}


enrolled students. The post hoc proportions tests show that only the comparisons of $\mathrm{S} 2$ with S0 and S1 are statistically significant ( $p=0.001$ in both cases). This means that S2 presents a better performance rate than the other two scenarios. The theoretical-practical assignment methodology (S1) therefore does not seem to help improve the number of passes over enrolled students.

\section{Success rate}

Proportions tests were conducted for the percentage of passes over the number of students who sat the exam in the corresponding academic year. No significant differences can be seen $(p=0.920)$, which indicates that the use of more active methodologies does not help to increase the success rate, despite the continuous assessment tests (S2) significantly increasing the percentage of exam shows.

\section{Exam grades}

The ANOVA test indicates that there are statistically significant differences between the means from one scenario to another. The post hoc analyses show that there is only a significant difference between the exam grades for scenarios S0 and S1 $(p=0.044)$. This difference is, however, contrary to what had been expected: as can be seen in Table 2, the highest mean exam grade is for S0 and the lowest for S1.

To summarise, it can be stated that the shift to more active methodologies does not guarantee an improvement in academic performance when measured by the success rate or the exam grade. However, an important finding is that in the teaching and assessment scenario with the most active methodologies used, i.e. S2, in which continuous assessment tests were done, the percentage of passes over the total number of students enrolled, i.e. the performance rate, significantly increases when compared to both a single examination (S0) and theoretical-practical assignments (S1). The same is not true of the teaching tools used in S1 compared to S0, since in that case the number of students sitting the exam did not change significantly compared to S0.

This means that, for the course and context considered, where there are high noshow rates and students find it difficult to pass tests, the continuous assessment tests (S2) appear to be an appropriate way of improving academic performance. They may not result in higher grades in the exam, or increase the percentage of passes over students that sit the exam, but they do have a clear effect on the rate of students that sit the exams, i.e. they significantly reduce the no-show rate and consequently increase the number of passes in absolute terms, by increasing the rate of passes over enrolled students.

\section{Assessable activities as a predictor of academic performance}

This section analyses the strength of the relationship between the optional assessable activities and academic performance in S1 and S2.

\section{Pass the course}

We first focused on the pass variable as the academic performance indicator. The variable that indicates student participation in each year's activities and the three 
control variables were included as independent variables. What is being tested is the extent to which his/her doing the activities can help predict or explain a student's passing the course.

Tables 4 and 5 set out the basic data for the logistic regression. In these, the Omnibus tests on the model coefficients show that there are significant improvements in the models over the reference models for each regression, and the HosmerLemeshow goodness-of-fit tests show that the models are also significant.

According to the Cox and Snell and Nagelkerke pseudo $R^{2}$, the percentage of variance explained by the models is about $9.5-14 \%$ in $\mathrm{S} 1$, and about $16-24 \%$ in $\mathrm{S} 2$. The predictive ability of the two models is $72.9 \%$ in S1 and $80.8 \%$ in S2, representing a clear improvement over random classification.

With regard to the predictors, in the upper halves of Tables 4 and 5, it can be seen that only the variable of interest (doing assessable activities) and the constant in S1 (but not in S2) are statistically significant in the resulting models. The control variables (shift, gender and student repeating subject) are not significant. The regression coefficient (column B) for the doing assessable activities variable is greater than zero in both cases, which indicates that it has a positive effect on passing. Nevertheless, there is a difference in the strength of the impact in the two cases. In fact, when the reasons for the advantages (column $\operatorname{Exp}(\mathrm{B})$ ) are compared in the two tables, the pass advantage of students who do the assessable activities compared to those who do not do them is noticeably greater (over double) in S2 than in S1 (specifically, 9.9 times for S2 and 4.4 for S1).

\section{Exam grades}

For S1 and S2, the grades for the assessable activities have been correlated with those for the examination. Both correlation coefficients are statistically significant, but there is a higher correlation between the exam grade and the continuous assessment test grade $(r=0.54 ; p<0.001)$ than the theoretical-practical assignment grade $(r=0.31 ; p<0.001)$ and it therefore has a higher predictor value. The continuous assessment test grade can explain up to $30 \%$ of the examination grade's variance, whilst the assignment grade only explains $9 \%$.

Table 4. Logistic regression analysis of passes in S1.

\begin{tabular}{|c|c|c|c|c|c|c|c|c|}
\hline \multirow[b]{2}{*}{ Predictors } & \multirow[b]{2}{*}{$B$} & \multirow[b]{2}{*}{ SE } & \multirow[b]{2}{*}{ Wald } & \multirow[b]{2}{*}{ df } & \multirow[b]{2}{*}{ Sig. } & \multirow[b]{2}{*}{$\operatorname{Exp}(B)$} & \multicolumn{2}{|c|}{$\begin{array}{l}95 \% \mathrm{CI} \text { for } \\
\operatorname{EXP}(B)\end{array}$} \\
\hline & & & & & & & Lower & Higher \\
\hline Shift & -0.367 & 0.268 & 1.881 & 1 & 0.170 & 0.693 & 0.410 & 1.171 \\
\hline Gender & -0.278 & 0.244 & 1.300 & 1 & 0.254 & 0.757 & 0.470 & 1.221 \\
\hline Repeating subject & 0.237 & 0.269 & 0.778 & 1 & 0.378 & 1.268 & 0.748 & 2.148 \\
\hline Doing activities & 1.476 & 0.261 & 31.983 & 1 & 0.000 & 4.376 & 2.624 & 7.299 \\
\hline Constant & 0.633 & 0.253 & 6.282 & 1 & 0.012 & 1.883 & & \\
\hline Fit tests & $\chi^{2}$ & df & Sig. & \multicolumn{5}{|c|}{ Variance explained } \\
\hline Omnibus tests & 42.052 & 4 & 0.000 & \multirow{2}{*}{\multicolumn{3}{|c|}{$\begin{array}{c}\text { Cox and Snell } R^{2} \\
0.095\end{array}$}} & \multirow{2}{*}{\multicolumn{2}{|c|}{$\begin{array}{c}\text { Nagelkerke } R^{2} \\
0.140\end{array}$}} \\
\hline Hosmer \& Lemeshow & 4.217 & 6 & 0.647 & & & & & \\
\hline
\end{tabular}


Table 5. Logistic regression analysis of passes in S2.

\begin{tabular}{|c|c|c|c|c|c|c|c|c|}
\hline \multirow[b]{2}{*}{ Predictors } & \multirow[b]{2}{*}{$B$} & \multirow[b]{2}{*}{ SE } & \multirow[b]{2}{*}{ Wald } & \multirow[b]{2}{*}{ df } & \multirow[b]{2}{*}{ Sig. } & \multirow[b]{2}{*}{$\operatorname{Exp}(B)$} & \multicolumn{2}{|c|}{$\begin{array}{l}95 \% \mathrm{CI} \text { for } \\
\operatorname{EXP}(B)\end{array}$} \\
\hline & & & & & & & Lower & Higher \\
\hline Shift & -0.006 & 0.256 & 0.001 & 1 & 0.981 & 0.994 & 0.602 & 1.641 \\
\hline Gender & -0.378 & 0.246 & 2.355 & 1 & 0.125 & 0.685 & 0.423 & 1.100 \\
\hline Repeating subject & 0.198 & 0.253 & 0.608 & 1 & 0.435 & 1.218 & 0.742 & 2.002 \\
\hline Doing activities & 2.298 & 0.269 & 73.211 & 1 & 0.000 & 9.952 & 5.879 & 16.846 \\
\hline Constant & -0.494 & 0.292 & 2.870 & 1 & 0.090 & 0.610 & & \\
\hline Fit tests & $\chi^{2}$ & $\mathrm{df}$ & Sig. & \multicolumn{5}{|c|}{ Variance explained } \\
\hline Omnibus tests & 86.157 & 4 & 0.000 & \multirow{2}{*}{\multicolumn{3}{|c|}{$\begin{array}{c}\text { Cox and Snell } R^{2} \\
0.163\end{array}$}} & \multirow{2}{*}{\multicolumn{2}{|c|}{$\begin{array}{c}\text { Nagelkerke } R^{2} \\
0.243\end{array}$}} \\
\hline Hosmer \& Lemeshow & 10.224 & 7 & 0.176 & & & & & \\
\hline
\end{tabular}

\section{Conclusions}

This study has analysed two research questions:

(1) Do more active T\&AM help to improve academic performance?

The results indicate that grades do not improve in any of the two most active scenarios analysed compared to the control scenario. In fact, there has even been a fall in the case of S1, which can be attributed to students' overconfidence due to the marks received in the assessment activities. However, we did find that S2 significantly reduces the number of students who drop out of the subject throughout the course and obtains a higher pass rate with regard to enrolled students (but not with respect to exam shows). S1, however, fails to have any effect in this regard. The overall conclusion is that a more active type of scenario can result in improved academic performance, but it is the choice of suitable activities for implementing active T\&AM that could mark the difference (Tang \& Austin, 2009; Wang, 2008). S1 does not increase the number of passes and, in addition, worsens the exam grades, so it is not a suitable scenario for our OM course. However, although S2 fails to improve exam grades, it is able to increase the number of passes. Therefore, in our case, multiple choice tests throughout the course have proven to be much more suitable than periodic assignments. These findings are in line with some prior studies. For instance, Peters, Kethley, and Bullington (2002) found that requiring graded homework had a negative effect on exam performance, and Douglas, Wilson, and Ennis (2012) argued that multiple-choice tests work more effectively when used in conjunction with other methods.

(2) To what extent can student involvement in more active T\&AM predict academic performance?

We found that student participation in the proposed assessable activities increases the likelihood of passing and, to some extent, predicts their exam grades. These results are significantly higher in S2 than in S1. Specifically, there is twice the likelihood of passing and the predictive power of the assessable activities grade is more than three times higher.

This study presents some limitations that should be borne in mind when assessing and interpreting the results. One limitation is that participation in assessable activities was voluntary and therefore its effect on performance cannot be accurately measured. For this reason, no comparisons have been made between the students 
who participated in them and those who did not, and the study has focused primarily on comparing the scenarios.

Furthermore, although many of the variables that may affect academic performance have been controlled for (teachers, students, teaching materials, examinations, etc.), there are at least three aspects that vary from one scenario to another (assessable activities, use of IT and assessable activities grade as a percentage of the final grade). This implies that the effects of each of these elements cannot be assessed individually, which is a constraint and a source of future research. However, in our opinion, the main element that differentiates one scenario from another is the type of assessable activities, and much of the variation in academic performance can be attributed to this.

Another important issue is that T\&AM could impact on academic performance in other ways connected with perceived learning, difficulty, utility, satisfaction, motivation and acquired skills (Kanet \& Barut, 2003; Larson \& Chung-Hsien, 2009). Determining what this impact is presents a challenge for future research.

\section{Notes on contributors}

Macarena Sacristán-Díaz is associate professor of OM at the University of Seville. She has been involved in various research projects in the areas of AMT, SCM and performance. Her current research principally focuses on lean production and SCM. Her articles have appeared in major international journals such as JOM, IJOPM, IJPE and IJPR.

Pedro Garrido-Vega is associate professor of $\mathrm{OM}$ at the University of Seville. He is the coauthor of two books and several chapters in books on OM. He has published in IJOPM, IJPE and $U B R$, among others. His current research interests are SCM, High Performance Manufacturing and Healthcare Operations.

Rafaela Alfalla-Luque is associate professor of OM at the University of Seville. She is the author of articles in major journals, including IJOPM, PPC and IJPE, a number of books and many conferences papers. Her current research principally focuses on Supply Chain Management, Megaproject Management and Teaching OM.

María-del-Mar González-Zamora is associate professor of $\mathrm{OM}$ at the University of Seville. Her current research focuses on Service OM and the design and creation of business games for transparent learning environments based on System Dynamics. She has published in major journals, including $J O M$, $J S M$ and $S \& G$.

\section{References}

Alfalla-Luque, R., Medina-López, C., \& Arenas-Márquez, F. J. (2011). Mejorando la formación en Dirección de Operaciones: la visión del estudiante y su respuesta ante diferentes metodologías docentes [Improving training in Operations Management: The student vision and their response to different teaching methods]. Cuadernos de Economía y Dirección de la Empresa, 14, 40-52.

Arquero, J. L., \& Romero-Frías, E. (2013). Using social network sites in higher education: An experience in business studies. Innovations in Education and Teaching International, $50,238-249$.

Arquero-Montaño, J. L., Jiménez-Cardoso, S. M., \& Joyce, J. (2004). Skills development, motivation and learning in financial statement analysis: An evaluation of alternative types of case studies. Accounting Education, 13, 191-212.

Barkley, A. (2006, June). The determinants of college student performance: The role of assessment method. Paper presented at the WAEA annual meeting, Alaska, USA. 
Collaud, G., Gurtner, J. L., \& Coen, P. F. (2000). Design and use of a hypermedia system at the University level. Journal of Computer Assisted Learning, 16, 137-147.

Crespo-Tejero, N., Palomo-Vadillo, M. T., \& Méndez-Suárez, M. (2012). El efecto del absentismo universitario en el expediente académico y en la percepción de sus causas [The effect of university absenteeism on academic records and on the perception of its causes]. Educade, 3, 47-65.

Daymont, T., \& Blau, G. (2008). Student performance in online and traditional sections of an undergraduate management course. Journal of Behavioural and Applied Management, 9, 275-294.

Douglas, M., Wilson, J., \& Ennis, S. (2012). Multiple-choice question tests: A convenient, flexible and effective learning tool? A case study. Innovations in Education and Teaching International, 49, 111-121.

Durán-Santomil, P., Maside-Sanfíz, J., Catorna-Agra, S., \& Rodeiro-Pazos, D. (2013). ¿ Es el nuevo sistema de evaluación del EEES realmente diferente del sistema tradicional? [Is the new EHEA assessment system really different from the traditional system?] Educade, 4, 77-96.

Dziuban, C. D., Hartman, J. L., \& Moskal, P. D. (2004). Blended learning. EDUCAUSE Center for Applied Research Bulletin, 7, 1-12.

Fish, L. (2008). Graduate student project: Employer operations management analysis. Journal of Education for Business, 84, 18-30.

Friday, E., Friday-Stroud, S. S., Green, A. L., \& Hill, A. Y. (2006). A multi-semester comparison of student performance between multiple traditional and online sections of two management courses. Journal of Behavioral and Applied Management, 8, 66-81.

Ginns, P., \& Ellis, R. A. (2009). Evaluating the quality of e-learning at the degree level in the student experience of blended learning. British Journal of Educational Technology, 40, 652-663.

Gracia-Expósito, E., \& De la Iglesia-Villasol, M. C. (2007, July). Absentismo y resultados de los alumnos [Absenteeism and student outcomes]. Paper presented at the XVI Jornadas de la Asociación de Economía de la Educación, Gran Canaria, Spain.

Holbert, K. E., \& Karady, G. G. (2009). Strategies, challenges and prospects for active learning in the computer-based classroom. IEEE Transactions on Education, 52, 31-38.

Kanet, J. J., \& Barut, M. (2003). Problem-based learning for production and operations management. Decision Sciences Journal of Innovative Education, 1, 99-118.

Larson, D., \& Chung-Hsien, S. (2009). Comparing student performance: Online versus blended versus face-to-face. Journal of Asynchronous Learning Networks, 13, 31-42.

Liaw, S. S., Huang, H. M., \& Chen, G. D. (2007). Surveying instructor and learner attitudes toward e-learning. Computers \& Education, 49, 1066-1080.

López-Bonilla, J. M., \& López-Bonilla, L. M. (2015). The multidimensional structure of university absenteeism: An exploratory study. Innovations in Education and Teaching International, 52, 185-195.

López-Pérez, M. V., Pérez-López, M. C., \& Rodríguez-Ariza, L. (2011). Blended learning in higher education: Students' perceptions and their relation to outcomes. Computers \& Education, 56, 818-826.

Marklin Reynolds, J., \& Hancock, D. R. (2010). Problem-based learning in a higher education environmental biotechnology course. Innovations in Education and Teaching International, 47, 175-186.

McLaren, C. H. (2004). A comparison of student persistence and performance in online and classroom business statistics experiences. Decision Sciences Journal of Innovative Education, 2, 1-10.

Medina-López, C., Alfalla-Luque, R., \& Arenas-Márquez, F. J. (2011). Active learning in Operations Management: Interactive multimedia software for teaching JIT/Lean Production. Journal of Industrial Engineering and Management, 4, 31-80.

Medina-López, C., Alfalla-Luque, R., \& Marín-García, J. A. (2011). La investigación en docencia en Dirección de Operaciones: Tendencias y retos [Research on teaching in operations management: Trends and challenges]. Intangible Capital, 7, 507-548.

Merril, G. B., \& Galbraith, C. S. (2009). Learning outcomes and instructional delivery method in professional and business related courses: An empirical study controlling for course and instructor differences. Journal of Business and Behavioral Sciences, 21, 18-38. 
Naslund, D. (2005). Online testing for logistics and operations management. Decision Sciences Journal of Innovative Education, 3, 357-365.

Parra, P., Baena, C., Jiménez, C. J., \& Valencia, M. (2008, July). Presencia y abandono de alumnos en nuestras asignaturas [Student attendance and drop outs from our courses]. Paper presented at the VIII Congreso de Tecnologías Aplicadas a la Enseñanza de la Electrónica, Zaragoza, Spain.

Pascual-Ezama, D., Camacho-Miñano, M., Urquía-Grande, E., \& Müller, A. (2011). Criterios de evaluación en el marco EEES [Assessment criteria in the EHEA]. Educade, 2, 67-83.

Peng, C. Y. J., Lee, K. L., \& Ingersoll, G. M. (2002). An introduction to logistic regression analysis and reporting. The Journal of Educational Research, 96, 3-14.

Peters, M., Kethley, B., \& Bullington, K. (2002). The relationship between homework and performance in an introductory operations management course. Journal of Education for Business, 77, 340-344.

Polito, T., Kros, J., \& Watson, K. (2004). Improving operations management concept recollection via the Zarco experiential learning activity. Journal of Education for Business, 79, 283-286.

Rúa-Vieytes, A., \& Gónzález-Martínez, C. I. (2004, September). Predicción del rendimiento académico final a partir de pruebas previas en asignaturas cuantitativas [Prediction of final academic performance based on previous tests in quantitative subjects]. Paper presented at the meeting of ASEPUMA, Murcia, Spain.

Sacristán-Díaz, M., Garrido-Vega, P., González-Zamora, M. M., \& Alfalla-Luque, R. (2012). Why do students skip class and not sit exams? Data and reflections on university absenteeism and exam no-shows. Working Papers on Operations Management, 3, 101-112.

Tang, T. L., \& Austin, M. J. (2009). Students' perceptions of teaching technologies, application of technologies, and academic performance. Computers \& Education, 53, $1241-1255$.

Tejedor, F. (2003). Poder explicativo de algunos determinantes del rendimiento en los estudios universitarios [Explanatory power of some determinants of performance in university studies]. Revista española de Pedagogía, 224, 5-32.

Wang, Q. (2008). A generic model for guiding the integration of ICT into teaching and learning. Innovations in Education and Teaching International, 45, 411-419.

Wang, Y. S., Wang, H. Y., \& Shee, D. Y. (2007). Measuring e-learning systems success in an organizational context: Scale development and validation. Computers in Human Behavior, 23, 1792-1808. 